University of Pennsylvania Carey Law School

Penn Law: Legal Scholarship Repository

Faculty Scholarship at Penn Law

3-3-2011

\title{
Tying and the Rule of Reason: Understanding Leverage, Foreclosure, and Price Discrimination
}

Herbert J. Hovenkamp

University of Pennsylvania Carey Law School

Follow this and additional works at: https://scholarship.law.upenn.edu/faculty_scholarship

Part of the Antitrust and Trade Regulation Commons, Economic Policy Commons, Industrial

Organization Commons, Law and Economics Commons, and the Policy Design, Analysis, and Evaluation Commons

\section{Repository Citation}

Hovenkamp, Herbert J., "Tying and the Rule of Reason: Understanding Leverage, Foreclosure, and Price Discrimination" (2011). Faculty Scholarship at Penn Law. 1864.

https://scholarship.law.upenn.edu/faculty_scholarship/1864

This Article is brought to you for free and open access by Penn Law: Legal Scholarship Repository. It has been accepted for inclusion in Faculty Scholarship at Penn Law by an authorized administrator of Penn Law: Legal Scholarship Repository. For more information, please contact PennlawIR@law.upenn.edu. 


\title{
Tying and the Rule of Reason:
}

\section{Understanding Leverage, Foreclosure, and Price Discrimination}

\author{
Herbert Hovenkamp ${ }^{1}$
}

\section{Introduction}

Because most litigated tie-ins have not seemed to create or reinforce power in any market, their function may lie elsewhere. This paper considers dominant firms use ties to exploit whatever power they already have over the tying product. Price discrimination is the most important means of doing so. It entered the debate not as a ground for condemnation but as a more innocent explanation for tying than foreclosure and "leverage." Rather than expand or reinforce a defendant's power in any market, many ties merely provide a convenient way to price the tying product. Although a pricediscriminating tie might cover most purchasers of a tied product and thus foreclose a substantial share of the tied market, effective price discrimination neither requires nor typically generates a significant foreclosure or other impairment of the tied market's structure or performance. Further, similar price discrimination results can usually be achieved by means that are more socially costly.

But should the tie that merely increases the exploitation of some customers be condemned on that account? This question is highly artificial, and the answer will not make much difference in many real cases. First, the tying seller may have no market power to exploit. In Jefferson Parish, for example, the tying seller was a hospital facing substantial competition and thus was probably unable to charge patients (or their sophisticated insurers) supracompetitive prices. ${ }^{2}$ Second, even a monopolist's tie-ins need not exploit any customer incrementally, for lawful non-tying vehicles will often have the same result. ${ }^{3}$ Third, any incremental exploitation that does occur is sometimes more than offset by the distributional benefits enjoyed by those who pay less than the uniform, nondiscriminatory price that would otherwise prevail. ${ }^{4}$ Fourth, that pure distributional issue is seldom presented because price typically affects output. Those who pay more usually purchase less, thereby depressing output and increasing the social cost of the defendant's power over the tying product. However, price discrimination often brings other customers lower prices than would otherwise prevail. The benefitted customers demand more, thereby increasing production and use and reducing the social cost of the defendant's power over the tying product. The net effects are often too indeterminate to count for or against tying, either generally or in particular cases. In the general run of cases, however, ties that facilitate price discrimination are more likely to increase welfare than reduce it. Further, while it does not benefit every single customer, on balance it benefits more customers than it harms, and very likely by a greater amount.

\footnotetext{
${ }^{1}$ Ben V. \& Dorothy Willie Professor of Law, University of Iowa.

${ }^{2}$ Jefferson Parish Hosp. Dist. No. 2 v. Hyde, 466 U.S. 2 (1984); see 10 ANTITRUST II1733.

${ }^{3}$ See, e.g., 9 ANTITRUST $\llbracket 1711 \mathrm{~b} 1-3$ \& e. Of course, the non-tying alternatives may be less effective.

${ }^{4}$ See, e.g., id. at $\mathrm{I} 1711 \mathrm{~b} 4 \& \mathrm{f}$.
} 
Nevertheless, while antitrust law aims primarily at practices that suppress rivalry, it can also address the identifiable practice, if any, that always or nearly always exploits consumers incrementally and overall and that does so without serving any legitimate functions. This is clearest when production and use are also likely to be affected.

The courts have not focused on this issue or deliberated on its answer. Some courts simply assume that consumer exploitation brought about by price discrimination ties is anticompetitive. ${ }^{5}$ By contrast, the Supreme Court's Jefferson Parish decision seems to say that mere exploitation of customers is not grounds for worrying about tying. ${ }^{6}$ The opinion repeatedly emphasized tying law's object of preventing impairment of competition in the tied market, apparently to the exclusion of any other concern. The Court seemed indifferent to the exploited buyer made to take an unwanted product.

[W] hen a purchaser is "forced" to buy a product he would not have otherwise bought even from another seller in the tied-product market, there can be no adverse impact on competition because no portion of the market which would otherwise have been available to other sellers has been foreclosed. ${ }^{7}$

In an earlier passage, the Jefferson Parish Court also suggested, with some ambiguity, that tying law ignored mere exploitation of customers:

[1] [T] he law draws a distinction between the exploitation of market power by merely enhancing the price of the tying product, on the one hand, and by attempting to impose restraints on competition in the market for a tied product, on the other. [2] When the seller's power is just used to maximize its return in the tying product market, where presumably its product enjoys some justifiable advantage over its competitors, the competitive ideal of

\footnotetext{
${ }^{5}$ Hirsh v. Martindale-Hubbell, 674 F.2d 1343, 1349 (9th Cir.), cert. denied, 459 U.S. 973 (1982) (finding no price discrimination in this case but suggesting that "[t]ying arrangements are viewed with disfavor [and] ... prohibited because they are thought to facilitate price discrimination"), citing Moore $v$. Jas. H. Matthews \& Company, 550 F.2d 1207, 1213 (9th Cir. 1977).

Curiously, the Hirsh court declared simultaneously that "leverage" objections have largely been discredited because ties do not generally alter the single monopoly profit inherent in the tying product. The court apparently disaggregated the several senses of "leverage" into (1) possibly greater profit when tied and tying products are used in fixed proportions, (2) price discrimination when those products are used in variable proportions, and (3) possible effects on entry into the tied or tying markets. The court dismissed the first but emphasized the second and third as evils, failing to see that such use-intensity price discrimination can ordinarily be achieved in other ways, as Judge Schwarzer pointed out in Casey v. Diet Center, 590 F. Supp. 1561, 1570 \& n.13 (N.D. Cal. 1984) (tie exploited franchisees no more than a "variable royalty based on a percentage of [the franchisee's] revenue"). Casey also noted that price discrimination need not be economically harmful at all. Ibid. Along with Hirsh, see Byars v. Bluff City News Company, 609 F.2d 843, 861 (6th Cir. 1979) (price discrimination an evil of tying) and Martino $v$. McDonald's Systems, 625 F. Supp. 356, 359 (N.D. Ill. 1985) (suggesting that price discrimination reveals "the extension of market power" into the market for the tied product);

${ }^{6}$ See Jefferson Parish Hosp., 466 U.S. 2; see 10 ANTITRUST I1733.

${ }^{7}$ Jefferson Parish Hosp., 466 U.S. at 16.
} 
the Sherman Act is not necessarily compromised. [3] But if that power is used to impair competition on the merits in another market, a potentially inferior product may be insulated from competitive pressures. [4] This impairment could either harm existing competitors or create barriers to entry of new competitors in the market for the tied product, and [5] can increase the social costs of market power by facilitating price discrimination, [6] thereby increasing monopoly profits over what they would be absent the tie. ${ }^{8}$

Until clauses \#5 and \#6, the Court seems to approve increased profits that merely reflect preexisting power over the tying product. Even those clauses absolve profits that could have been obtained without the tie. To be sure, the reference in clause \#6 to profit that could not otherwise be obtained might condemn incremental profit above that which could be obtained from non-tying price discrimination. However, it follows clause \#5, which refers to "greater social cost of market power," which seemingly refers to the possible output effects of price discrimination ${ }^{9}$ and which flows in clause \#4 from the impairment of competition in the tied market through harm to existing rivals or new entry there. These passages from Jefferson Parish suggest indifference to the tie that merely helps exploit preexisting power in the tying market without worsening market structure or raising "social cost" by reducing output.

In Illinois Tool, whose holding was that market power would not be presumed from the mere fact that the tying product is patented, the Supreme Court discussed price discrimination only briefly. ${ }^{2}$ The Court concluded that the presence of price discrimination, just as the presence of the patent, was not sufficient to warrant an inference of market power. The Court observed that "it is generally recognized that [price discrimination] occurs in fully competitive markets." 3 It thus implicitly concluded that price discrimination itself would not serve to condemn a tie. In Sheridan the Seventh Circuit acknowledged as much. The court observed that tying can facilitate price discrimination and extract more revenue from more intense users. Nevetheless, "price discrimination does not violate the Sherman Act unless it has an exclusionary effect. And a monopolist doesn't have to actually take over the market for the tied product in order to discriminate....,

\footnotetext{
${ }^{8} I d$. at $14-15$ (numbered references added; citations and footnotes omitted). The bulk of the references in the Court's footnotes emphasized not only that tying may be adopted to achieve price discrimination but that such discrimination can sometimes produce socially desirable results. See 9 ANTITRUST I1711.

${ }^{9}$ See 9 ANTITRUST I1711 for the difference between output effects and incremental exactions from some customers.

${ }^{2}$ Illinois Tool Works, Inc. v. Independent Ink, Inc., 547 U.S. 28 (2006) (to the extent it is relevant, HH was consulted by the defendant).

${ }^{3} I d$. at 44 , citing 9 ANTITRUST II711 in the previous edition and WILLIAM M. LANDES \& RICHARD A. POSNER, THE ECONOMIC STRUCTURE OF INTELLECTUAL PROPERTY LAW 374-75 (2003); William J. Baumol \& Daniel G. Swanson, The New Economy and Ubiquitous Competitive Price Discrimination: Identifying Defensible Criteria of Market Power, 70 ANTITRUST L.J. 661, 666 (2003).

${ }^{4}$ Sheridan v. Marathon Petroleum Co., LLC, 530 F.3d 590, 593 (7th Cir. 2008).
} 


\section{Incremental Exploitation as Detriment}

Indifference to incremental exploitation in judging ties would rest on the general legal permission for the otherwise lawful holder of monopoly power to charge whatever the traffic will bear-including such discrimination as the market allows through metering and similar devices. ${ }^{10}$ Several, but not all, rationales for that well-established permission might indicate an absolute "entitlement" to exploit such power via any vehicle that antitrust law does not already condemn on other grounds. Other rationales are consistent with prohibiting an identifiable class of conduct, if any, that always or usually intensifies monopolistic exploitation without benefiting any customers or the economy, and thus that does not require an antitrust tribunal to judge the reasonableness of actual prices or output.

The clearest reason for not trying to control a monopolist's price directly is uncertainty about the proper price. Without guides to propriety, it seems unfair to punish a firm for charging a price that a tribunal later judges to have been excessive. Moreover, the tribunal itself is ill-equipped to determine the reasonable price and repeatedly to redetermine it as supply and demand conditions change. Antitrust courts have rightly abjured that role. ${ }^{11}$

However, our inability or unwillingness to transform such tribunals into price-control agencies does not prevent us from condemning an identifiable practice that always, or even typically, exploits some consumers without benefitting others or the economy, thus dispensing with any assessment of prices in particular cases.

\section{Suppressed Rivalry, Incentives and Legitimate Rewards}

The competitive impulses that antitrust law promotes derive not only from the fear of losing out to rivals but also from the hope of outcompeting them in order to enjoy excess profits as the fruit of "superior skill, foresight, and industry" or "business acumen." 12 The hope of excess returns inspires the rivalry that antitrust law favors. Although such profits might result from luck, entry barriers, or rivals' incompetence, we cannot usually distinguish the source and want to encourage the pursuit of excess gains through desirable behavior. Preserving those incentives seems entirely consistent with confining the focus of antitrust law to improper behavior creating or maintaining market power, while leaving those who obtain power by proper means to enjoy its fruits. Similarly, although the policy of granting monopolies to encourage invention has not validated every patent license restraint that might enhance the patentee's rewards, the illicit restraints have primarily been those that limit otherwise possible competition with the patentee, not those that merely increase its returns. ${ }^{13}$

\footnotetext{
${ }^{10}$ See 3A ANTITRUST $\mathbb{I I I 7 2 0 ,} 721$.

${ }^{11}$ See id. at $\$ 1720$.

${ }^{12}$ The quoted phrases are from, respectively, United States v. Aluminum Company, 148 F.2d 416, 430 (2d Cir. 1945), and United States v. Grinnell Corporation, 384 U.S. 563, 571 (1966).

${ }^{13}$ See, e.g., 9 ANTITRUST $\llbracket 1701 \mathrm{a}-\mathrm{b}$.
} 


\section{Higher Tied Product Prices with Neither Injury to Rivals}

\section{nor Higher Consumer Prices}

The least warrant for antitrust intervention occurs when higher tied product prices fail to result from foreclosure of rivals and are not reflected in higher consumer prices. For example, most franchise ties (1) fail to foreclose any rival from anything because the tied product is a common ingredient or other input into franchising; (2) fail to result in higher consumer prices because the franchise's business is in competition with other businesses, both franchised and unfranchised.

The franchise tying cases, which are discussed in detail elsewhere ${ }^{14}$ have a set of ingredients that are common to nearly all of them. First, The plaintiffs are franchisees rather than end-use consumers, and the market share of the franchise as a whole is far too small to warrant any conclusions that consumers pay more because of the tie. Second, rival businesses are not foreclosed from anything by the tie, generally for two reasons. (1) because the franchisor lacks significant power in any market; and (2) because the tied products are usually common inputs such as herbs and spices, ${ }^{15}$ the rental of a common building or other restaurant site, ${ }^{16}$ pizza dough made from ordinary ingredients, ${ }^{17}$ or cookies or other common food products. ${ }^{18}$ Third, the only high price is that paid by the franchisee, and thus the dispute almost always reduces being one between the franchisor and franchisee about the size of the franchise fee. That may of course be a contract problem, may involve fraud in the case of the franchisee who was deceived into signing an unfavorable agreement, or may implicate a state franchisee protection statute. ${ }^{19}$ Interfering with contract prices, however, is not the job of antitrust tribunals.

The Queen City Pizza decision illustrates this. ${ }^{20}$ The plaintiffs were franchisees of Domino's Pizza, the franchisor and defendant. The plaintiffs complained that Domino's required franchisees to purchase the various ingredients for pizzas, particularly pizza dough mix, from Domino's own subsidiary at significantly higher prices than the franchisees might pay alternative vendors. To be sure, the plaintiff may have had a contract dispute with its franchisor about whether it was required to purchase Domino's dough or other supplies. Also, Domino's was very likely using higher prices on dough to "meter" the franchisee's sales as a way of collecting the franchise fee, and it is certainly possible that Domino's was attempting to charge a larger franchise fee than it had

\footnotetext{
${ }^{14}$ On power issues, see 2B ANTITRUST 1519.
}

${ }^{15}$ Siegel v. Chicken Delight, 448 F.2d 43, 46-47 (9th Cir. 1971), cert. denied, 405 U.S. 955 (1972).

${ }^{16}$ E.g., Principe v. McDonald's Corp., 631 F.2d 303, 304 (4th Cir. 1980), cert. denied, 451 U.S. 970 (1981).

${ }^{17}$ E.g., Queen City Pizza v. Domino's Pizza, 124 F.3d 430 (3d Cir.1997), cert. denied, 523 U.S. 1059 (1998).

${ }^{18}$ Collins v. Int'1 Dairy Queen, 980 F. Supp. 1252 (M.D. Ga. 1997).

${ }^{19}$ See generally 2B ANTITRUST II519.

${ }^{20}$ Queen City Pizza v. Domino's Pizza, 922 F. Supp. 1055, 1061 (E.D. Pa. 1996), aff'd, note 17. See also Maris Distributing Company v. Anheuser-Busch Incorporated, 302 F.3d 1207 (11th Cir. 2002), cert. denied, 537 U.S. 1190 (2003), which overruled the Collins decision, and embraced the reasoning of the Third Circuit in the Queen City Pizza case. 
charged at some earlier period in this franchise arrangement.

But high contract prices alone do not form the basis of an injury to competition unless sales in the market for the contracted-for product are reduced. In this case there was no allegation that the Domino's pizza dough tie-in had any measurable effect at all on the markets for flour, salt, baking powder, or other ingredients that might go into pizza dough. To be sure, there may have been alternative sellers who wished to sell pizza dough to Domino's franchisees but were prevented by the franchise contract, but injury to competition would occur only if these contracts denied these rival sellers access to a significant portion of that market. This was not alleged and, in any event, seems unreasonable on its face. Even a very large franchisor such as Domino's consumed only a trivial portion of the nation's flour and salt. As long as the rivals have an ample market in which to sell their dough or equivalent products made from the same ingredients and processes, there is no injury to competition.

Further, as long as Domino's is a competitor in the pizza business, retail customers cannot be injured by the tie. To the extent Domino's franchisees pass off higher priced dough via higher pizza prices, customers will turn to other pizza sellers, whose dough makers will in fact be benefitted rather than injured by Domino's high dough prices.

\section{"Pure" leveraging without foreclosure or price discrimination:}

\section{Exclusive dealing distinguished}

Early on some courts adopted a "leverage" theory that a tie could harm consumers by forcing them to pay a monopoly price for a "tied" product even in the absence of foreclosure. These courts largely did not recognize the possibility of price discrimination. ${ }^{5}$ For example, in the Carbice decision, an early patent "misuse" case, the Supreme Court condemned an arrangement under which the seller of a patented ice box required those who used it to purchase its dry ice as well. The tie was nonforeclosing, since dry ice, which occurred naturally and was readily manufactured, was not patentable. ${ }^{6}$ Nevertheless, Justice Brandeis wrote, the requirement was an unlawful leveraging of the ice box patent because it enabled the patentee to "derive its profit not from the invention on which the law gives it a monopoly, but from the unpatented supplies with which it is used." If a monopoly could be contractually expanded in this way, a patentee "might conceivably monopolize the commerce in a large part of the unpatented materials used in its manufacture. The owner of a patent for a machine might thereby secure a partial monopoly on the unpatented supplies consumed in its operation.,"

\footnotetext{
${ }^{5}$ On price discrimination ties, see 9 ANTITRUST $\llbracket 1711$.

${ }^{6}$ Dry ice had been discovered in the 1830s by Charles Thilorier, a French chemist, as the residue from rapid evaporation of liquid carbon dioxide. See Duane H.D. Roller, Thilorier and the First Solidification of a "Permanent Gas (1835), 43 Isis 109 (1952).

${ }^{7}$ Carbice Corp. v. Am. Patents Dev. Corp., 283 U.S. 27, 31-32 (1931).

${ }^{8 .} I d$.
} 
This "pure" leveraging theory that does not require either foreclosure nor price discrimination rests on a simple economic fallacy that a firm can earn greater profits by charging more than its "profit-maximizing" price. The producer of an ice box that used dry ice as a refrigerant would charge a price for the box that already reflected any market power that it might possess. This price would thus already reflect the existing market price of the dry ice itself, because customers require the box/dry ice combination. As a result, a seller could tie dry ice and sell it at a monopoly price only by cutting the price of the ice box, or else its price would rise above the profit-maximizing level. ${ }^{9}$ The Bowman article repudiating the theory indicated that most of the ties to which courts had applied the theory were instances of price discrimination, and that tying of this sort typically involved a price cut in the tying product and a price increase in the tied product. The subsequent case law has borne this out. ${ }^{10}$

This fear of "pure" leveraging, without foreclosure and without an articulated concern about price discrimination, largely accounts for the development of the per se rule against tying in the 1940s and 1950s. Because it did not require proof of foreclosure, structural analysis such as that applied in rule of reason cases was believed unnecessary. This form of the leverage theory also explains why exclusive dealing, covered by the same section of the Clayton Act, developed a rule of reason analysis even though exclusive dealing often has greater exclusionary force than does tying. For example, while tying might foreclose rivals from selling a particular tied product, exclusive dealing typically excludes them from the defendant's entire line. ${ }^{11}$ In exclusive dealing cases, unlike tying, the courts did not see the "leveraging" of two related products by requiring that they be purchased from the same seller.

Several conclusions emerge. First, there is a modest though not compelling case for condemning a class of conduct if it always or usually exploits some consumers incrementally without benefitting other consumers with lower prices or expanded output, even when the conduct has no other detrimental effects. As we shall see later, tie-based price discrimination does not satisfy this prerequisite for general condemnation because it can often be achieved equally well by other means, and it is as likely as not to benefit other consumers with lower prices and the economy with expanded output. The pure "leverage" theory, which assumed that all customers could be exploited even in the absence of foreclosure, never withstood careful analysis.

Second, antitrust law does not and should not require an assessment of prices and output in the particular case unless the evidence is very strong. This principle generally

\footnotetext{
${ }^{9}$ This leverage theory was initially exploded by Ward Bowman, Tying Arrangements and the Leverage Problem, 67 YALE L.J. 19, 21-23 (1957); see also Richard Markovits, Tie-Ins, Reciprocity and the Leverage Theory, 76 YALE L.J. 1397 (1967).

${ }^{10}$ See 9 ANTITRUST I1711b; see Erik N. Hovenkamp \& Herbert Hovenkamp, Tying Arrangements and Competitive Harm, 52 ARIZ. L. REV. 925, 942 \& n.77 (2010), available at http://papers.ssrn.com/sol3/papers.cfm?abstract_id=1443284; Christina Bohannan, IP Misuse and Foreclosure, 96 IOWA L. REV. 475 (2011), available at http://papers.ssrn.com/sol3/papers.cfm?abstract_id=1474407. For a generally contrary view, see Einer Elhauge, Tying, Bundled Discounts, and the Death of the single Monopoly Profit Theory, 123 HARV. L. REV. 397 (2009).

${ }^{11}$ See 11 ANTITRUST TIII1800, 1802, 1820, 1821.
} 
precludes examining the actual output and prices associated with a particular defendant's tie-in. In any event, none of the theories about how tying harms competition have attempted this. The pure leverage theory simply assumed that the price of a tying combination was higher than the price of separately sold components. To the extent that assumption has been subjected to theoretical assessment or verification it is false, particularly in situations where the secondary market is not perfectly competitive. The price discrimination theory does not currently have the tools to assess individual price/output effects. Price discrimination ties benefit some customers and may injure others. Overall welfare effects are very likely positive but impossible to measure in particular cases. Foreclosure theories rely on traditional antitrust structural analysis rather than direct measurement of price/output effects.

Third, it is important not to confuse "leverage" and "foreclosure." The court were often ambiguous, speaking of the leveraging of a second "monopoly" in the tied product, without distinguishing between higher prices themselves or actual exclusion. By losing sight of this distinction the courts began treating tying harshly even though it involved tied products that were ordinary commodities in which actual market exclusion was impossible.

Although society would lose little by condemning the tie that merely increases the exploitation of some customers (if we could identify the case), it would also gain little when exploitation beyond that achievable though lawful alternative is relatively rare. Moreover, any such exploitation of some customers may accompany benefits for other customers-such as those who receive the lower of two discriminatory prices-so that net exploitation is rarer still. Furthermore, the incremental revenues that impel a seller to use a tie may often result from increased production and use.

\section{Tying and Price Discrimination}

Tying came to be feared as a device by which a seller "levered" power over a tying product into power over a tied product. ${ }^{1}$ That fear accounts for the law's early hostility toward tying arrangements. In fact, however, the tied product in many litigated cases has often been a staple item, such as dry ice, paper or salt. Because the predominant uses of the staple were elsewhere, the tying seller had no expectation of power in the tied market, so commentators began several decades ago to explore alternative motivations for tying. They identified price discrimination as a likely explanation for many ties. ${ }^{2}$ Instead of gaining power or otherwise affecting competition in the tied market, a tying seller uses the tie simply to maximize its revenues from the tying product through price discrimination. ${ }^{3}$

\footnotetext{
${ }^{1}$ See 9 ANTITRUST IIT1701, 1710.

${ }^{2}$ E.g., GeORGE J. STIGLER, THE THEORY OF PRICE 215-16 (rev. ed. 1952); Ward S. Bowman, Tying Arrangements and the Leverage Problem, 67 YALE L.J. 19, 23-24 (1957); Meyer Burstein, A Theory of Full Line Forcing, 55 Nw. L. REV. 62 (1960). Other literature is summarized in HERBERT HOVENKAMP, FEDERAl ANTITRUST POLICY: THE LAW OF COMPETITION AND ITS PRACTICE §10.6e (4th ed. 2011) and FREDERIC M. SCHERER \& DAVID M. ROSS, INDUSTRIAL MARKET STRUCTURE AND ECONOMIC PERFORMANCE ch. 13 (3d ed. 1990).

${ }^{3}$ For additional routes by which a tie helps exploit preexisting power over the tying product, see 9 ANTITRUST I1712.
} 
The defendant would use ties to facilitate price discrimination only when it thereby increases its own profits. Although that increment might represent a mere transfer of wealth from some customers to the defendant, its source might also be an expansion of sales at more competitive prices to lower-value users of the tying product. Common forms of discrimination, including tying, are likely to have that beneficial result. We can conclude mainly that the detriments of price discrimination are not so surely harmful in the generality of cases to support absolute illegality for tying. Moreover, it seems very doubtful that judges and juries can assess the net impact of a particular price discrimination tie on production and use relative to output at the prices that would have prevailed in the absence of any discrimination. The social value of guessing about such matters is also doubtful when similar effects are likely to result from lawful, non-tying methods of discrimination. In sum, price discrimination is not a warrant for condemning a tie that is not objectionable on other grounds.

\section{Utility and Prerequisites of Price Discrimination}

Suppose that a monopolist has constant costs of $\$ 1$ per unit and three customers, each of whom desires one unit of the product and is willing to pay up to $\$ 5, \$ 2$, and $\$ 1$, respectively, for it. If unable to discriminate, the monopolist will sell one unit for $\$ 5$, earning \$4 profit; at lower prices it will sell more but earn less. With "perfect" discrimination, it will sell one unit at each price, yielding $\$ 8$ revenue and $\$ 5$ profit.

Without discrimination, only the highest-value customer would receive the product in this example. By contrast, perfect (first degree) discrimination expands output to the perfectly competitive level, bringing the product to the customer who is just willing to pay its cost of production and thus benefitting society. The benefit is unequivocal here because this discrimination forces no one to pay any more than it would have to pay in its absence; even the highest-value customer pays only the $\$ 5$ that a nondiscriminating seller would charge. This is not always true, for we shall see later that discrimination can extract more from some customers than the uniform price that would otherwise prevail. The immediate point is that discrimination may bring production and use closer to the competitive level and may sometimes do this without even exploiting the highestvalue users.

This simple example also shows three prerequisites for successful discrimination. First, the seller must possess some degree of market power. This can be readily explained. The lower of the discriminatory prices must equal or exceed marginal cost or else it would be unprofitable. Therefore, the higher price must exceed such costs and could not be maintained were there intense competition. ${ }^{4}$ Second, the seller must be able to identify those who are willing to pay the higher price. Third, the seller must be able to prevent those who buy at the low price from reselling to those asked to pay more ("arbitrage"). Subsequent illustrations will show how tying arrangements can identify customers valuing the tying product more highly and can also prevent low-price buyers from undermining the discrimination.

Though serving to implement price discrimination, a tie might, of course, foreclose

\footnotetext{
${ }^{4}$ See 2B ANTITRUST 9517 , which notes, however, that the amount of power needed to support price discrimination can be extremely small.
} 
enough of the tied market to affect competition there. ${ }^{5}$ Because no foreclosure is needed to bring about price discrimination, it can be appraised independently of any foreclosure effect or threat.

The most common discrimination produced by variable-proportion tying-namely, of charging customers differently according to the intensity with which they use a product - is a form of second degree price discrimination. Tie-ins have been used for this purpose along with many alternative devices of undoubted legality. Although we cannot be absolutely sure of price discrimination's effects, this "metering" function of price discrimination is likely to expand production and use of the tying product and thereby to improve resource allocation. This benefit, together with the benefit to the low-price customers, offsets the possible loss of consumer surplus to the high-price customers.

The discussion below also explains why price discrimination accomplished through tying does not inefficiently transfer output from higher value to lower value customers, thus answering one objection that has been stated against it. While that is a characteristic of third degree price discrimination, nearly all variable proportion ties represent instances of second degree discrimination, although a few may incorporate both types of discrimination.

\section{Tying and "Degrees" of Price Discrimination}

Since early in the twentieth century economists have classified price discrimination into three types, or "degrees," which can involve significantly different practices, and with significantly different effects. In first degree price discrimination, sometimes called "perfect" price discrimination, a seller is able to identify the maximum customer willingness to pay for each unit of each good that it is selling. Output under first degree price discrimination is the same as under competition, but there is no consumer surplus at all. Because sellers can rarely identify buyer willingness to pay with such precision, first degree price discrimination is rare to nonexistent in the real world. One example that comes close is the so-called Dutch auction, in which the auctioneer starts with a very high price and then announces lower prices until a bidder accepts. Assuming the complete absence of strategic behavior, such an auction would claim very close to each buyer's reservation price on each sale. ${ }^{12}$

By contrast second degree price discrimination occurs when sellers are unable to make ex ante judgments about buyer willingness to pay, but can make observations relating customer behavior of various kinds to willingness to pay. The most common example is the quantity discount, which gives lower prices to purchasers of larger amounts. But there are also arrangements such as airline classes of seats, which permits passengers to select a price based on amenities. To the extent that the price is not proportional to cost differences between the classes of service, the seller is price

\footnotetext{
${ }^{5}$ See 9 ANTITRUST IIII1704-1707.

${ }^{12}$ An ordinary auction does not have this result because the winning bidder might have been willing to bid even more, thus leaving some consumer surplus with the buyer. See Johannes Horner \& Larry Samuelson, Managing Strategic Buyers (SSRN Working Paper, Sept. 8, 2010), available at http://papers.ssrn.com/sol3/papers.cfm?abstract_id=1673898.
} 
discriminating. Most two part tariffs are a form of second degree price discrimination. In such a scheme the seller charges a fixed fee for "entry" plus a fee for use. For example, a car rental company might charge $\$ 25$ per day plus 30 cents a mile for a rental car. Or an electric utility might charge a \$35 per month "base" fee, plus 20 cents per kilowatt hour. Depending on how the fee is structured the seller can obtain different rates of return from buyers who use more or fewer variable units.

A variable proportion tying arrangement is a form of second degree price discrimination. The seller typically offers a "fixed," or durable product at a price that is lower than the free standing price it could otherwise charge. However, then it ties some good that is used in varying amounts by different buyers. For example, a seller with some market power in its computer printer might have a "standalone" market price of $\$ 100$. Ink cartridges might be sold competitively at a price of $\$ 10$. The printer maker might then charge $\$ 70$ for the printer, which is its cost or less, and tie ink cartridges at a price of $\$ 20$. If a printer user consumers 3 cartridges over the life of the printer the manufacturer breaks even on this deal, but it earns more from printer users who use more than 3 cartridges.

In this illustration the printer/cartridge tie has three quite different effects. Customers who consume more than 3 cartridges are worse off. Customers who would have purchased the printer anyway but who consume fewer than three cartridges are better off. In addition, however, the price reduction in the printer from $\$ 100$ to $\$ 70$ brings additional customers into the printer market who would not otherwise have purchased. While customers in the first class are injured by the arrangement, customers in the second two classes are benefitted. ${ }^{13}$

That this theory explains many if not most variable proportion ties seems fairly clear. One unfortunate consequence of the per se rule against tying is that courts have not made consistent records on the question of how tying defendants allocate the price between the tying and tied good. Those cases that report the price, however, are virtually uniform that the tying product price was cut to a lower level than it would otherwise have been sold, often to cost or below, ${ }^{14}$ and sometimes even to zero. ${ }^{15}$

${ }^{13}$ See Erik N. Hovenkamp \& Herbert Hovenkamp, Tying Arrangements and Competitive Harm, 52 ARIZ. L. REV. 925 (2010), available at http://papers.ssrn.com/sol3/papers.cfm?abstract_id=1443284.

${ }^{14}$ See Xerox Corp. v. Media Sciences, Inc., 660 F. Supp. 2d 535, 539 (S.D.N.Y. 2009) (printer/ink tie - "As is true of other printer manufacturers, Xerox generally sells its printers at a low margin or a loss, hoping to earn a profit through later sales of high margin ink"). Among the earliest cases involving variable proportion ties, see Henry v. A.B. Dick Company, 224 U.S. 1 (1912), where the patentee sold its mimeograph machine at less than its costs but tied ink, stencils, and other supplies and assessed a high markup on those. See A.B. Dick Co. v. Henry, 149 F. 424, 425 (C.C.N.Y. 1907) ("The evidence establishes that the complainants sell the machines at a loss, less than the actual cost of making, relying on sales of supplies therefor for a profit. The complainants have sold about 11,000 of these machines under this license restriction.”); Heaton Peninsula Button Fastening Co. v. Eureka Specialty Co., 77 Fed. 288, 289 (6th Cir. 1896) (button fastening machine sold at "actual cost to the maker, they expecting a profit on their monopoly alone from the sale of fasteners or staples to those having the machine."); 
Finally, third degree price discrimination occurs when a seller is able to identify customer classes ex ante and charge these classes different prices based on perceived willingness to pay. For example, a seller might charge different prices to commercial and residential users. ${ }^{16}$ Third degree price discrimination has one unique characteristic that may magnify any harm that it causes: it creates a "discontinuity" in demand that

Cortelou v. Charles Eneu Johnson \& Co., 138 F. 110 (C.C.N.Y. 1905), rev'd, 145 F. 933 (2d Cir. 1906) (tie of patented duplicating machine to stencils: "The evidence is that the present selling price of the rotary neostyle machine is $\$ 50$, but that its cost to the manufacturer is about $\$ 64$."); see also Motion Picture Patents Co. v. Universal Film Mfg. Co., 243 U.S. 502, 516 (1917) (noting patentee's argument that the public benefitted "by the sale of the machine at what is practically its cost"); Static Control Components, Inc. v. Lexmark Int'1, Inc., 487 F. Supp. 2d 830 (E.D. Ky. 2007) (printer manufacturer received lower price for cartridges subject to a restriction requiring a single use and replacement with another Lexmark cartridge than if sold without the restriction). In other literature, see Tony Smith, "Xbox 360 costs third more to make than it sells for," THE REGISTER (Nov. 24, 2005), available at http://www.theregister.co.uk/2005/11/24/xbox360_component_breakdown/ (last visited July 20, 2009) (noting Microsoft's strategy of below cost sale of hardware game box, accompanied by high prices for Microsoft's own games plus royalty rates on license fees from independent game producers). In marketing this is sometimes called razor + blade pricing, and it applies to goods that are tied by technological incompatibility as well as those that are contractually tied. See Wesley R. Hartmann \& Harikesh S. Nair, Retail Competition and the Dynamics of Consumer Demand for Tied Goods (Stanford Business School Working Paper, Dec. 4, 2007), available at http://papers.ssrn.com/sol3/papers.cfm?abstract_id=1085009; see also Richard Gil \& Wesley R. Hartmann, Why Does Popcorn Cost so Much at the Movies? An Empirical Analysis of Metering Price Discrimination (Stanford Univ. Graduate School of Business Research Paper, Jan. 2008), available at http://papers.ssrn.com/sol3/papers.cfm?abstract_id=1088451 (movie theaters tie concession food products by prohibiting attendees from bringing in their own; high food prices are offset by lowered admission prices); see Christopher Soghoian, Caveat Venditor: Technologically Protected Subsidized Goods and the Customers who Hack Them, 6 Nw. J. TECH. \& INTELL. PROP. 46 (2007) (providing several examples, focusing on technological ties).

See Edward Iacobucci, A Switching Costs Explanation of Tying and Warranties, 37 J. LEGAL STUD. 431 (2008) (describing strategies of using low foremarket prices compensated by high aftermarket prices).

${ }^{15}$ See, e.g., Kentmaster Mfg. Co. v. Jarvis Prods. Corp., 146 F.3d 691 (9th Cir. 1998), amended, 164 F.3d 1243 (9th Cir. 1999) (defendant provided durable meat cutting equipment at no charge to meat cutters, but charged higher prices for aftermarket parts). Compare a common distribution mechanism of soft drink dispensing machines, which provides the machines to owners of locations where vending occurs at a price of zero, but the machine may stock only that supplier's brand of soft drinks. See Vending Solutions, Coca-Cola Vending Machine, http://www.vendingsolutions.com/coke-vending-machines/ (Coca-Cola; free dispensing machine to plant locations containing forty employees or more, but only Coca-Cola products can be dispensed in the machine). Among franchise ties, see Siegel v. Chicken Delight, Inc., 448 F.2d 43 (9th Cir. 1971) (franchisor charged no franchising fee or royalty, but required franchisees to purchase tied products at higher-than-market prices).

${ }^{16}$ E.g., Gen. Talking Pictures Corp. v. Western Elec. Co., 305 U.S. 124 (1938) (licensing of technology to produce sound amplifiers at different rates to producers for commercial use and for home use); ProCD, Inc. v. Zeidenberg, 86 F.3d 1447 (7th Cir. 1996) (licensing of database to commercial and residential users at different rates); see Christina Bohannan, Copyright Preemption of Contracts, 67 MARYLAND L. REV. 616 (2008). 
effectively transfers sales from higher to lower value customers and as a result destroys some consumer surplus. For example, suppose that a software producer charges $\$ 400$ to businesses for use of its software, but only $\$ 200$ to noncommercial buyers. A prospective commercial buyer willing to pay $\$ 399$ for the software would not buy it; however, a home user willing to pay no more than $\$ 201$ would. Re-assigning this unit from the commercial buyer to the homeowner reduces total consumers' surplus by $\$ 198 .^{17}$ As a result of this phenomenon economists have been able to show that third degree price discrimination that does not increase total output necessarily reduces consumer welfare (surplus). ${ }^{18}$ This is not the case of second degree price discrimination.

The economic literature generally deals with variable proportion ties as seconddegree price discrimination. ${ }^{\mathrm{S} 18}$ First of all, as noted above, third-degree price discrimination involves a seller's prior segregation of groups of customers based on willingness to pay. ${ }^{\mathrm{S} 19}$ Tying does not; rather, the tying firm selects the products and places them on the market, with the same price schedule to all. Customers identify themselves by selecting the portion of the schedule that they want. Further, there is no transfer of output from high value to low value buyers. For example, in the printer/ink cartridge tie illustration every customer who values the printer by $\$ 70$ or more purchases one, and purchases cartridges to the point that the value they place on an additional cartridge falls below $\$ 20$. "At the margin" all customers are treated alike and receive the same incremental value from the product.

${ }^{17}$ Of course, in the case of a product such as software or the patent license in General Talking Pictures, marginal cost is very likely extremely low, perhaps close to zero. In the case of nonrivalrous goods such as licenses generally, sales to one person do not subtract from the availability of the good to others. In that case, a unit is not exactly "reassigned" from high value to low value customers the way a costly item produced under capacity constraints, such as a truck or refrigerator, would be. The number of units sold to high value users very likely has little impact on the number available to lower value users, and vice-versa. The price discrimination is just a tool for maximizing profits within each grouping. See CHRISTINA BOHANNAN \& HERBERT HOVENKAMP, CREATION WITHOUT RESTRAINT: PROMOTING LIBERTY AND RIVALRY IN INNOVATION, ch. 1 (2011).

${ }^{18}$ E.g., Marius Schwartz, Third-Degree Price Discrimination and Output: Generalizing a Welfare Result, 80 AM. ECON. REV. 1259 (Dec. 1990); Richard Schmalensee, Output and Welfare Implications of Monopolistic Third-degree Price Discrimination, 71 AM. ECON. REV. 242 (1981); Hal R. Varian, Price Discrimination, in 1 HANDBOOK OF INDUSTRIAL ORGANIZATION 600 (Richard Schmalensee \& Robert D. Willig, eds., 1989); see also ARTHUR C. PIGOU, THE ECONOMICS OF WELFARE, II.17.6 (4th ed. 1932) (observing this result).

${ }^{\text {S18}}$ See, e.g., JEAN TIROLE, THE THEORY OF INDUSTRIAL ORGANIZATION 147 (1998) (ties a form of second-degree price discrimination); see also Richard A. Posner, Vertical Restraints and Antitrust Policy, 72 U. CHI. L. REV. 229, 236 (2005) (same).

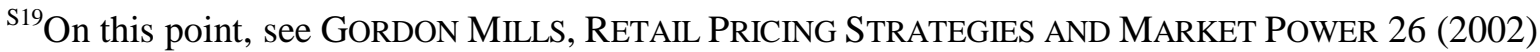
(difference between second- and third-degree price discrimination is that in second-degree discrimination seller cannot distinguish customers into diverse groups, but rather they self-select according to a pricing schedule that is the same for all). 


\section{Price Discrimination Tie as Risk Sharing Device}

Second degree price discrimination such as occurs under a variable proportion tie can also confer additional value by attracting customers who are uncertain about their potential use. Especially for a new product or business investment, potential customers may readily see its utility without fully appreciating at the outset just how useful the new product will be. For example, a potential user of a computer or a copier might be unsure how much it would use the machine and would therefore be unwilling to commit itself to pay a substantial price or rental. The user would, however, be willing to pay a higher price if it turned out that it used the machine a great deal. Accordingly, the seller might set a relatively low base rental for those who agreed to pay an additional but contingent sum for each use of the machine.

Similarly, a franchisee might be unwilling to pay a high periodic royalty fee before it knows if the franchise will be a great success. The franchisor might accommodate the franchisee with a contract requiring only a small base license fee coupled with additional royalty payments based on the franchisee's volume. If the franchise does not prosper, the franchisee is out only the small base fee; if business booms, the franchisor will reap a share of the franchisee's prosperity. In this way, the franchisor acquires risk-averse franchisees who bear relatively little downside risk if the business is only moderately successful. Because the franchisor bears a great portion of the risk, it also reaps a greater reward if the franchisee is highly successful.

These risk-sharing situations reflect imperfect information. At the outset of the transaction, neither the supplier nor the user knows whether the user will turn out to be a high-intensity, high-value user or not. Requiring payment according to actual use helps both parties deal successfully with their imperfect information. ${ }^{6}$ More generally, price discrimination ties serve to change the buyer's cost structure, making relatively less of its investment a fixed cost that may be substantially nonrecoverable, and relatively more a variable cost. In an extreme case the manufacturer of a costly piece of durable hardware may supply it at no cost to the user, and earn its entire markup on tied supplies.

\section{Price Discrimination Ties and Alternative "Metering" Devices}

There are many ways to vary the price according to each customer's intensity of use. A meter on a copy machine might count the number of copies made so that customers may be charged for each copy in addition to a fixed monthly charge. Similarly, franchisees often pay a percentage of their revenues as a royalty to the franchisor. ${ }^{7}$ With meters or percentage royalties, high-volume users pay more and cannot escape

\footnotetext{
${ }^{6}$ See Tyler A. Baker, The Supreme Court and the Per Se Tying Rule: Cutting the Gordian Knot, 66 VA. L. REV. 1235, 1280 (1980); Richard S. Markovits, Tie-Ins, Reciprocity and the Leverage Theory, 76 YALE L.J. 1397, 1411 (1967).

${ }^{7}$ See, e.g., Principe v. McDonald's Corp., 631 F.2d 303, 304 (4th Cir. 1980), cert. denied, 451 U.S. 970 (1981) (franchisees pay " 2.2 percent of their gross receipts as royalties under the franchise agreement and 8 percent as rent under the lease").
} 
the discrimination by purchasing anything - machine or franchise-from the low-volume users who pay less.

Variable proportion ties also serve this metering function. When high-volume users of product $A$ need large quantities of complementary product $B$, selling or leasing $A$ on condition that the customer also purchase its requirements of $B$ at a profitable price from the defendant achieves price discrimination. ${ }^{.}$Film might be tied to a traditional camera, paper to a copying machine, or ink cartridges to a computer printer. ${ }^{9}$ The more such customers use the tying product, the more they must buy of the tied product. For example, a manufacturer might charge a price near its costs in selling or renting a copying machine to those customers willing to buy their paper requirements from it. By setting paper prices above the competitive level, the defendant captures a little economic profit on each paper sale. In effect, the high-intensity user pays more for the machine, recognizing its greater value to it than to the low-volume user. And because the paper must be purchased from the machine maker at a "high" price, there is nothing the low-volume user can profitably resell to the high-volume user. Such price discrimination cannot be undermined.

By whatever device, mechanical metering has its costs. Meters usually accompany products that are leased rather than sold and thus imply that the supplier bears the capital cost of continuing to own the machines used by others. ${ }^{10}$ The supplier also bears the costs of designing, installing, inspecting, maintaining, and reading the meter. These costs might be prohibitive when the meter is unreliable, or difficult to maintain, ${ }^{11}$ or requires visits to read that are unduly expensive in relation to value. For example, it is quite cheap for a car rental company to "meter" the car by reading the odometer, because the car comes equipped with this device anyway, and the odometer is read when the driver returns the car; so the incremental cost of reading the meter is very low. However, metering a home use printer or camera could impose significant additional costs in relation to the value of the product.

Similarly, revenue-based royalties require difficult and costly monitoring of the

\footnotetext{
${ }^{8}$ If the market price of the tied product is already supracompetitive because of insufficient competition in the tied market, the tying seller gains more excess profit by forcing the tied customers to take that product from it rather than from its competitors.

${ }^{9}$ E.g., Illinois Tool Works, Inc. v. Independent Ink, Inc., 547 U.S. 28 (2006) (tie of ink to printer head) (to the extent it is relevant, HH was consulted by the defendant); Static Control Components, Inc. v. Lexmark Intern., Inc., 615 F. Supp. 2d 575 (E.D. Ky. 2009) (ink cartridges to computer printer); see also IBM Corp. v. United States, 298 U.S. 131 (1936); Siegel v. Chicken Delight, 448 F.2d 43, 51 (9th Cir. 1971), cert. denied, 405 U.S. 955 (1972) (franchisee must buy paper plates from franchisor at premium price in lieu of franchise fee, which was zero).

${ }^{10}$ Because greater use may wear out the machine faster, varying the rental fee with use can also reflect depreciation independently of discrimination.

${ }^{11}$ See, e.g., Mid-America ICEE v. John E. Mitchell Co., 1973-2 Trade Cas. I[74,681 at 94,987 n.23 (D. Or.) (the meter did not work effectively with all products passing through the machine; servicing triggered it, and its delicacy meant frequent maladjustment).
} 
franchisee's accounts. Such costs can be larger or smaller than the costs of buying or producing and handling the tied supplies and monitoring the customer to detect its purchases of the tied product from other sources. In some instances, there may be no effective alternative at all.

Consider, for example, the defendant manufacturer who requires franchised dealers to use only its "genuine" repair parts. ${ }^{12}$ Although the manufacturer insists that only those parts guarantee proper functioning of the machine and thereby protect the manufacturer's reputation, price discrimination may be the object when its price exceeds any real quality premium over rival repair parts. In that event, those who need more repair parts because they use the machine more intensively-for example, drive a car farther or over more years-presumably value it more highly and effectively pay more for it than those who use it less. Without inducing the dealers performing a substantial portion of those repairs to use "genuine" parts, the defendant may have great difficulty in obtaining the postulated premium on those parts.

\section{No Shift from Higher Value to Lower Value Customers}

Nonforeclosing ties, which are tying arrangements that do not cause harm by excluding rivals, may extract higher prices from some customers, but the case for condemning them on that ground is very weak. ${ }^{\mathrm{S} 1}$ The means of extraction is usually a form of price discrimination, and the typical result is that, while some consumers are harmed, others will benefit. While some instances of price discrimination reduce welfare or result in higher consumer prices in the aggregate, most do not and segregating the two sets is extremely difficult. Many, if not most, variable proportion ties encountered in antitrust cases probably increase output, which makes a broad rule condemning them unwise. This is particularly likely to be true if a tying arrangement involves a lower price in the tying product, where the dominant firm has power, and a transfer of at least a portion of the monopoly overcharge to the tied product. The great majority of variable ties undoubtedly fall into this class.

While the economic literature on price discrimination and tying focuses on monopolists, many challenged ties occur in markets where the defendant has no more market power than generally results from product differentiation. Indeed, most franchise ties, which are variable proportion, occur in competitive albeit product differentiated markets. ${ }^{S 3}$ In those cases, a tie that includes a substantial price reduction in the tying

${ }^{12}$ See 9 ANTITRUST I1716c.

${ }^{\mathrm{S1}}$ For a contrary view, see Einer Elhauge, Tying, Bundled Discounts, and the Death of the Single Monopoly Profit Theory, 123 HARV. L.REV. 397 (2009); Joseph F. Brodley, The Economic Goals of Antitrust: Efficiency, Consumer Welfare, and Technological Progress, 62 N.Y.U. L. REV. 1020, 1036 (1987).

${ }^{\mathrm{S} 3}$ See, e.g., Kypta v. McDonald's Corp., 671 F.2d 1282 (11th Cir. 1982) (fast food; hamburgers and related products; tying of lease of location); Queen City Pizza v. Domino's Pizza, 124 F.3d 430 (3d Cir. 1997), cert. denied, 523 U.S. 1059 (1998) (pizza; tying of pizza dough, a commodity made of flour, oil, salt and water); Siegel v. Chicken Delight, Inc., 448 F.2d 43 (9th Cir. 1971) (fast-food fried chicken; 
product can increase the number of tying product sales significantly. For example, a franchisor may offer a very low entry price for its franchise, thus reducing franchisee risk and inducing many more franchisees to invest, but then tie various commodities or products that are used by the franchisee in proportion to its sales. The true monopoly case is the rare, but hardly unheard of, worst case scenario.

One unfortunate consequence of the historical per se rule against ties ${ }^{\mathrm{S} 8}$ is that questions about how price discrimination works in tying arrangements are irrelevant, as are questions about the impact of the tie on output. As a result, antitrust litigation has not made records on these issues and we know much less about them than we should. However, a nonforeclosing tie that involves a price reduction in the tying product, as most probably do, increases consumer access to that product. Variable proportion ties that involve reduced tying product prices generally serve to do two things. First, they change the purchaser's cost structure by giving it lower fixed costs but higher variable costs. For example, to the purchaser the printer is a fixed cost but the ink is a variable cost. A printer/cartridge tie that involves lower printer prices but higher ink prices serves to bring more printer customers into the market, although it also distorts usage decisions at the margin, because the ink price is higher. In addition, the increase in the seller output of printers can reduce production costs substantially if a significant proportion of printer design and production costs are fixed.

Variable proportion ties have been attacked on the premise that they "reallocat[e] output from high-value buyers to low value buyers." But the argument is based on the premise that they are a form of third-degree price discrimination or that the difference between second- and third-degree price discrimination is merely "semantics." ${ }^{2}$ That premise can then lead to the conclusion that variable proportion ties reduce consumer welfare even if they increase output, because the increased output accrues to consumers who place a lower value on the tied product (or the tying-tied combination), while higher prices and possible reduced output accrues to other higher-value consumers.

As noted above, however, the argument has no application to second-degree price discrimination, which covers all ties in which tying and tied product are offered at the same nominal price to all customers. ${ }^{19}$ To be sure, some ties may also contain attributes of third-degree price discrimination, but they would have to be more complex than the ordinary tie. For example, a manufacturer of printers and ink might tie printers

tying of spices and supplies); Little Caesar Enter., Inc. v. Smith, 34 F. Supp. 2d 459 (E.D. Mi. 1998)

(pizza; tying of paper plates and other products bearing franchisor's logo).

${ }^{\mathrm{S} 8}$ See 9 ANTITRUST I1720.

${ }^{\text {S9}}$ Elhauge, Tying, Bundled Discounts, 123 HARV. L. REV. at 431 \& n.89.

${ }^{19}$ Note that the argument might apply to other types of vertical restraints, such as vertical customer division or field of use restrictions in IP. For example, a supplier or segregates dealers serving businesses from those that serve homeowners may be engaging in third degree price discrimination. In general, this has not been a rationale for condemning either vertical restraints or field-of-use restrictions. 
and ink but also charge a higher price for either or both products to commercial users than to home users. In that case the printer/ink tie would be an instance of seconddegree price discrimination, while the differential price to commercial and home users would be an instance of third-degree price discrimination.

To be sure, second-degree price discrimination may lead to its own distortions from perfect competition, but they are much different distortions than third-degree price discrimination encounters, and there is at least as much reason for thinking that they "distort" the dominant firm's output back toward the competitive level rather than viceversa. The one problem second-degree price discrimination does not typically encounter is the discontinuities in marginal substitution that are characteristic of thirddegree discrimination. For example, if first-class flying is too straining on a person's budget as she does it more frequently, she is always free to shift part or all of her purchases to coach class. As the number of classifications in a second-degree price discrimination scheme is increased, the scheme comes closer to approximating firstdegree, or "perfect," price discrimination, under which each individual customer pays his or her reservation price and output increases toward the competitive level. ${ }^{516}$ In practice, few second-degree schemes reach anything close to that level of classification. However, variable proportion ties theoretically permit an infinite number of degrees depending on the number of tied units a purchaser buys.

At the same time, most variable proportion ties do not constitute first-degree price discrimination. While a well-executed printer/ink tie could accurately make prices proportional to the number of copies a person prints, it could not control for the fact that different purchasers place different values on each individual copy. For example, both a law firm drafting legal opinions on securities offerings and a printer of handbills about garage sales might print 1,000 pages weekly. As a result, if they purchased under the same tying arrangement they would pay the same amount per print. But given what is at stake, the law firm might value the printouts at many dollars per page, while the handbill printer values them at only a few cents. The variable proportion tie will not capture these differences in valuation and will thus permit at least some consumers to retain surpluses. In order to capture more, the printer maker would additionally have to engage in third degree discrimination as between the law firm and the handbill printer.

These facts suggest that most variable proportion tying arrangements are benign without even considering production or distribution cost savings, including economies of joint provision or improved quality control that independently justify ties. Further, even a variable proportion tie that reduces output cannot be shown to reduce welfare except in the unusual case where no customer benefits from the tie. ${ }^{\text {S27 }}$

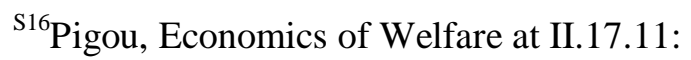

It is readily seen that the effects of monopoly plus discrimination of the second degree approximate towards those of monopoly plus discrimination of the first degree, as the number of different prices, which it is possible for the monopolist to charge, increases; just as the area of a polygon inscribed in a circle approximates to the area of the circle as the number of its sides increases. . . .

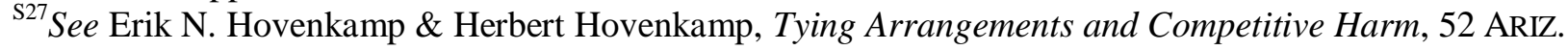

L. REV. 925 (2010), available at http://papers.ssrn.com/sol3/papers.cfm?abstract_id=1443284.. 
Finally, the economies that can result from such ties are pervasive and can be substantial, thus explaining the wide variety of ties that exist in competitively structured markets, including those for franchises and computer printers. ${ }^{\text {S28 }}$ For example, the higher output that results from lower tying product prices can also produce lower costs ifa significant portion of tying product production costs are fixed. As a result, the core concern of exclusive dealing and tying-arrangement analysis is not leverage. Rather, it remains concerned principally with the unreasonable exclusion of rivals, which is also the core concern of $\$ 2$ of the Sherman Act. That statute does not reach simple output reducing practices. But market exclusion is unlikely to result from practices imposed by a single firm unless it meets the market-share standards ordinarily required for unlawful monopolization.

\section{Package Pricing Under Differential Customer Demand}

Ties might be used in yet other ways to aid price discrimination. For example, a package price might enable a supplier to maximize revenues when it cannot practicably discriminate in price but its customers place differential values on the components in the package. ${ }^{22}$ This type of price discrimination applies even to fixed proportion ties. However, as in that case, it does not offer an independent ground for antitrust condemnation (although a tie that discriminates in this way might incidentally cause anticompetitive foreclosure). Indeed, such a practice can be output increasing and actually improve consumer welfare, depending on the nature of customer demand.

To illustrate, suppose a monopolist has two products, Alpha and Beta and that their costs of production are zero. Two customers want both products and are willing to pay more than cost, but their willingness to pay varies between the two, according to the following schedule:

\begin{tabular}{lll} 
& \multicolumn{2}{l}{ Willingness to pay } \\
Alpha & Beta \\
Customer 1 & 10 & 5 \\
Customer 2 & 3 & 11
\end{tabular}

\footnotetext{
${ }^{\mathrm{S} 28}$ On the sources of cost savings and product improvement that results from ties, see 9 ANTITRUST IIII1712-1718.

${ }^{22}$ See GeORGE J. STIGLER, THE ORGANIZATION OF INDUSTRY 165-166 (1968); George J. Stigler, United States v. Loew's, Inc.: A Note on Block-Booking, 1963 SUP. CT. REV. 152 (1963). Such packaging is sometimes referred to as "simulated" price discrimination because it does not involve true price discrimination at all, but only the sale of a package to two different buyers at the same price where the buyers place different values on different elements of the package. See HERBERT HOVENKAMP, FEDERAL ANTITRUST POLICY: THE LAW OF COMPETITION AND ITS PRACTICE §10.6e (4th ed. 2011); William James Adams \& Janet L. Yellen, Commodity Bundling and the Burden of Monopoly, 90 Q.J. ECON. 475 (1976).
} 
In this case the optimal strategy for the dominant firm is to package the two products together at a price of 14, and sell both products to both customers. The seller's surplus is 28. Customer 1's surplus is 1; customer 2's surplus is 0 .

Now suppose that tying and bundled discounting are forbidden, which means that the seller must set a price for Alpha and Beta individually. One choice would be for the seller to set a price of 10 for Alpha and 11 for Beta. In that case only customer 1 would purchase Alpha and only customer 2 would purchase Beta. So the seller's surplus would be 21; and the customer's surplus would be 0 .

Alternatively, the seller could charge a price of 3 for Alpha and 5 for Beta. In this case both customers would purchase both products. The seller's surplus would be 16. Customer 1 would have a consumer surplus of 7 and customer 2 would have a consumer surplus of 6 . Total consumer surplus would be 13.

But the important thing to note in this case is that if tying were not an option a rational seller would take the first choice above, giving itself returns of 21 and customers a surplus of zero. If bundling were permitted, though, the seller's returns would increase to 28, and consumers' surplus would also increase from zero to 1 . That is to say, not only would the tying in this case increase total welfare, it would also increase consumers' surplus. These outcomes can vary, however, and depend on the strength and direction of the buyers' preferences and also on the seller's costs. ${ }^{20}$

To be sure, we might prefer the more "competitive" outcome in which the monopolist made the separate sales at the lower prices to both customers. But a rational seller in our example would not do that, and we could reach that outcome only if we not only forbad tying but also regulated the seller's prices. So in this case a simple rule forbidding tying would reduce welfare (the sum of producer's and consumers' surplus) by 8 and it would also reduce consumers' surplus by 1 .

The illustration also indicates two common themes in tying law: the first is that increased profits very often come from increased output. In the film example involving a fixed proportion tie, just as in the general discussion of variable proportion ties above, tying often increases output. When tying increases output of either the tying or the tied product then increases in both general welfare and consumer welfare are likely, although certainly not invariable.

The second is that whether a particular outcome from forbidding tying increases or decreases total or consumer welfare depends critically on the numbers one chooses for the example. In most cases tying very likely increase welfare, but in some it does not. Further, the numbers are very difficult to determine in litigation and needing to determine them can greatly increase cost and decrease certainty.

Should the possible detriments of price discrimination condemn a tie that is otherwise harmless? Should the possible benefits redeem a tie that is deemed harmful on independent grounds? Do such detriments or benefits bear on the wisdom of per se illegality for tying?

${ }^{20}$.Professor Elhauge gives an example in which consumers' surplus is reduced. Elhauge, Tying, Bundled Discounts, 123 HARV. L. REV. at 406. 
Price discrimination can extract more from some customers than uniform prices and thereby transfer income from them to the supplier, other customers, or both. Such transfers, however, do not warrant condemning an otherwise harmless tie, even if that exploitation both (1) exceeds that which would otherwise result from alternative and lawful vehicles of discrimination and (2) offends antitrust policy. The reasons are two.

First, discrimination necessarily involves both higher- and lower-price customers. Focusing on the former's exploitation ignores the latter's gain in income. We have no reason to give greater weight to the former's loss more than to the latter's gain.

To be sure, there may be cases where the loss to high-priced customers is not entirely offset by the gain for low-priced customers. The seller would not discriminate, however, unless it also gains something from it. Even so, the lesser dollar gain of the lower-price customers may represent greater utility, although judging interpersonal utilities is usually thought impossible. In any event, this issue is mooted by the next one.

Second, a price for some customers that is below the uniform price that would otherwise prevail ordinarily brings greater use by them and thus moves production toward the competitive level, ${ }^{27}$ overshadowing any redistribution of income away from high-value users. Consumers as a class enjoy a net benefit when increased use and production result from price discrimination.

We saw earlier that production and use are likely to rise in the frequent case of price discrimination according to intensity of use. Although other forms of price discrimination are more ambiguous in their effects and might sometimes depress production and use, we cannot say that they usually or generally do so. Because this adverse possibility cannot be said to be more frequent than expansion of production and use toward the competitive level, it does not itself support a general condemnation of tie-ins.

The same agnosticism that rejects price discrimination as grounds for condemnation also rejects its use-expanding potential as an affirmative defense to a tie that is otherwise proven harmful. Economic theory does not allow us to say that price discrimination always increases use and production, and exploring the effects of a particular discrimination is too likely to be inconclusive. Moreover, disallowing the defense need not prevent beneficial price discrimination, which can often(though not always) be achieved via lawful alternative methods. ${ }^{30}$ As a result, we would not permit price discrimination to be used as a defense to a tie that is genuinely shown to be anticompetitive under the rule of reason.

\footnotetext{
${ }^{27}$ While greater physical output of, say, copying machines is easy to see, a more widely used franchise also increases the units sold under it and thus benefits consumers in the same way.

${ }^{30}$ See, e.g., Mid-America ICEE v. John E.Mitchell Co., 1973-2 Trade Cas. I74,681, 94,987-94,988 \& n.24. The court was satisfied that the defendant "had no anticompetitive intent.... Its main purpose was to establish an efficient meter price system; this was the simplest one it knew of." Moreover, as the court acknowledged, "Meter pricing itself serves the useful function of permitting royalties to vary with [the franchisee's] income." Nevertheless, the court held the tie illegal because less restrictive alternatives were available to accomplish the same purpose. Admitting the absence of any substantial effect in the tied product market, it believed that such an effect was "irrelevant" under existing law.
} 
However, in the case of nonforeclosing ties, ${ }^{31}$ where harm to competition is not proven but merely inferred under the per se rule from a substantial volume of tiedproduct commerce, ${ }^{32}$ a showing of price discrimination and presumptively increased output should serve to defend the tie. ${ }^{33}$

\section{Relevance of Lawful Alternatives}

Price discrimination need not depend upon tying. Instead of requiring users of copying machines to buy their paper from the machine maker at an elevated price, the machine maker might simply attach a meter that counted every copy made by the machine. Instead of requiring a fast-food franchisee to buy high-priced paper plates to measure patronage, the franchisor can base its fee on the franchisee's revenues. Such lawful alternatives are relevant in several ways. First, they demonstrate that antitrust law is frequently indifferent to price discrimination, at least when achieved without tying. Whether such indifference to non-tying discrimination amounts to affirmative approval or not, it means that the extent of price discrimination will be largely unaffected by the law of tying. When tying is forbidden, similar discrimination will typically be practiced by other and lawful means. It follows that price discrimination should be deemed neither an independent basis for condemning an otherwise lawful tie-in nor a redeeming virtue for otherwise unlawful tying. That is, even if price discrimination were regarded as evil, it would not be significantly reduced by condemning tying. Similarly, outlawing otherwise unlawful tying would not sacrifice the potential procompetitive benefits of price discrimination, which can be achieved mainly by other and lawful means. Notwithstanding some qualifications in the following elaboration, this reasoning reinforces the conclusion that price discrimination's effects are not sufficiently assured either to condemn an otherwise lawful tie or to save an otherwise unlawful tie.

By permitting so much price discrimination in so many contexts-for example, the metered machine or percentage-of-revenue franchise fee as well as the tie-has antitrust law affirmatively approved price discrimination as either harmless or even beneficial? An affirmative answer is supported by the proposition that firms with lawfully obtained market power may charge whatever the traffic will bear. On the other hand, the cases reveal neither express reasoning nor much analysis of a firm's price discrimination. Some judges have simply assumed that price discrimination via tying is undesirable $^{23}$ and thus may believe that the law's relative indifference to non-tying discrimination reflects a lacuna in statutory coverage. Sherman Act $\$ 2$ reaches only the single firm that is an actual or prospective monopolist whose conduct helps create or maintain that market power. ${ }^{24}$ Even if that were the exclusive focus of Sherman Act $\$ 2$, it would not necessarily validate tying agreements that are covered by $\$ 1$ or Clayton Act $\S 3$ and that might be forbidden without requiring the courts to examine particular prices or their effects.

\footnotetext{
${ }^{31}$ See 9 ANTITRUST 91725.

${ }^{32}$ See id. at $\mathbb{1} 1721$.

${ }^{33} \mathrm{See} 10$ ANTITRUST $91763 \mathrm{a}$.

${ }^{23}$ See 9 ANTITRUST $\llbracket 1710 \mathrm{~b}$.

${ }^{24}$ See 3 ANTITRUST I[650.
} 
Thus, although we believe that price discrimination should not itself be grounds for condemning tying, we cannot say that the law's relative indifference to most discrimination amounts to affirmative approval of price discrimination as legitimate and procompetitive. Nevertheless, we can say that antitrust law has not deemed discrimination so evil as relentlessly to prevent it. And we should recall that precedent has primarily emphasized substantial foreclosure and increased entry barriers-rather than increased profit or possible exploitation of some customers-as the evil addressed by anti-tying law. ${ }^{25}$

Whether feared or blessed, discrimination can neither condemn nor save tying when equivalent non-tying discrimination would replace the tie. In that event, outlawing the tie stops neither good nor bad discrimination. We presume that equivalent lawful discrimination is available, as in the metered machine or percentage-of-revenue franchise illustrations.

However, the lawful alternative might be more expensive to administer or less effective. In that event, condemning the tie might prevent discrimination's detriments or sacrifice its benefits. As noted before, it may require fewer resources to monitor a fastfood franchisee's purchase of cheaper paper plates from other sources than to determine the accuracy of its revenue accounts. Similarly, fewer resources may be needed to monitor a customer's purchase of supplies from others than to install, secure, maintain, and read a meter on a machine. Condemning such ties may simply lead to the substitution of the more expensive alternative, thus wasting social resources without ending any undesirable discrimination. It seems unwise to force the seller to adopt alternatives wasting resources or achieving fewer benefits without eliminating any detriments.

On the other hand, a lesser degree of discrimination might reduce whatever detriments are thought to be present. Indeed, the alternatives might be so much more expensive or less effective than the tie that the tieless seller simply charges a uniform price-thus stopping both good and bad discriminations. Notwithstanding those possibilities, it is probably impractical to vary the disposition of particular cases with predictions about the cost and utility of lawful alternative means of discrimination relative to the discrimination's effects. The alternatives cannot be assumed to be inferior merely because the defendant chose to adopt the tie. The defendant might have overlooked the alternatives or simply judged them no better (rather than inferior), or sought some objective beyond price discrimination. So long as a tie sacrifices no revenue, the defendant may choose the tie rather than an equivalent alternative in the hope, however remote, that it might possibly impair competition in the tied market or obstruct entry into the tying market.

Although the relative harms and benefits of alternative means of discrimination might be canvassed in each lawsuit, reliable conclusions will be rare, especially for discriminations involving different end uses of the tying product. Fortunately, we do not need to make such a canvass or adopt working presumptions about the adequacy of alternatives when the possible benefits or detriments of discrimination neither save an

\footnotetext{
${ }^{25}$ See 9 ANTITRUST $\mathbb{1 1 7 1 0 .}$
} 
otherwise harmful tie nor condemn an otherwise harmless one.

\section{Conclusion: the Compelling Case Against Tying's Per Se Rule}

At this writing some 35 years have passed since Fortner ${ }^{21}{ }^{21}$ and more 25 years since Jefferson Parish. $^{22}$ That seems long enough to endure recognition that an antitrust rule is no longer serving its purpose. When the concern is foreclosure, application of the rule of reason is clearly called for. Assessment of foreclosure requires determining the extent of any exclusion, and this requires a market definition. ${ }^{23}$ The appropriate foreclosure analysis in tying cases is not materially different than in exclusive dealing cases. In exclusive dealing the complaint is that rivals are excluded from access to a particular dealer or set of dealers. In tying the complaint is most typically that rivals in the tied market are foreclosed from tied product sales within that market. The Supreme Court recognized the need for market analysis already in its $\operatorname{Tampa}^{24}$ decision, and the courts have always applied a full rule of reason inquiry into exclusive dealing. ${ }^{25}$

Recent attempts in the scholarly literature to defend a per se rule have been based almost exclusively on concerns about leverage, or extraction of higher profits from consumers aside from any foreclosure possibility. The arguments for per se, or quasi per se, illegality rest on some subset of the following propositions, which were discussed in greater detail earlier: First, that there are instances in which a firm can extract additional profits from the customer by tying two products together. ${ }^{26}$ Second, that output is rarely increased by tying, mainly because the tying product price is not reduced or may even be increased; or alternatively, that output effects are unimportant and in any event are offset by the fact that ties reallocate "some output to buyers who put less value on it." 27 Third, that double marginalization does not occur or can be safely ignored. ${ }^{28}$ Fourth, that cost savings or product or service impovement are not primary motives for tying, and are thus best considered only as a defense.

On the first proposition, while the critique of the tying "leverage" theory remains robust, ${ }^{29}$ some instances of tying do have the result that some customers pay higher prices. This is particularly true of variable proportion ties in which high intensity users of the tied product pay more for the combination as

${ }^{21}$ United States Steel Corp. v. Fortner Enters., 429 U.S. 610 (1977).

${ }^{22}$ Jefferson Parish Hosp. Dist. No. 2 v. Hyde, 466 U.S. 2 (1984).

${ }^{23}$ See 9 Antitrust Law I1704.

${ }^{24}$ Tampa Elec. Co. v. Nashville Coal Co., 365 U.S. 320 (1961). See 11 Antitrust Law I1801i; on Tampa's relevance to tying foreclosure, see 9 Antitrust Law I1709c3.

${ }^{25}$ See 11 Antitrust Law $\mathbb{1} 1820$.

${ }^{26}$ See 9 Antitrust Law IIT1700d1, 1710. See also id., I1701b. While the Motion Picture Patents case discussed in \$1701b spoke of leverage the real concern in that decision was foreclosure. And see I1706 (leveraging of sequential monopolies).

${ }^{27}$ Einer Elhauge, Tying, Bundled Discounts, and the Death of the Single Monopoly Profit Theory, 123 Harv.L.Rev. 397, 405 (2009). See also id. at 430-434. And see Nicholas Economides, Tying, Bundling, and Loyalty/Requirement Rebates, in Research Handbook on the Economics of Antitrust Law (Einer Elhauge, ed., 2011).

${ }^{28}$ For example, neither Elhauge, id. nor Economides, id., discuss double marginalization as a rationale for tying or bundling. For further development, see 9 Antitrust Law ITI1704c4, 1712; and Erik N. Hovenkamp \& Herbert Hovenkamp, Tying Arrangements and Competitive Harm, 52 Ariz. L. Rev. 925, 958-963 (2010), available at http://papers.ssrn.com/sol3/papers.cfm?abstract_id=1443284. In the context of vertical integration by the monopolist, see 3B Antitrust Law I7758; in the context of vertical mergers, see 4A Antitrust Law I1022.

${ }^{29}$ See 9 Antitrust Law I1711. 
a result of the redistribution of prices that the tying involves. ${ }^{30}$ However, in most of these cases the tying arrangement brings many new customers into the market and results in lower prices for the lower use customers. Further, in the great majority of cases the gains experienced by the gainers are greater than the losses suffered by the losers. ${ }^{31}$ Even in these cases, the proposition that some customers suffer losses depends on an assumption that neither the elimination of double marginalization, discussed below, nor the creation of production scale economies is sufficient to offset the higher prices.

Second, output effects strongly weigh in favor of presumptive legality and rule of reason treatment. One unfortunate consequence of the per se rule, however, is that price changes and output effects that result from a tie have not been relevant to questions of legality. As a result the decisions typically do not mention them. Occasional decisions do, however, and with no exceptions of which we are aware these cases state that as a consequence of the tie the defendant reduced the price of the tying product from its standalone profit maximizing level, often dramatically, sometimes to below cost, and sometimes even to zero. ${ }^{32}$ The result is that more of the tying product is sold, and in some cases much more, depending on the elasticities of demand. When a customer is brought into this market who was not in it under separate sales, its purchases are a pure consumer gain, even at a higher price for the tied product. ${ }^{33}$ Further, some lower intensity customers gain even if they had purchased previously, because the price cut in the tying product is more than enough to offset the price increase in the tied product. ${ }^{34}$ Some of the courts have recognized this by denying damages to tying customers who cannot showed that the sum of the two prices they paid under tying is greater than the separate product prices. ${ }^{35}$

To illustrate these effects, imagine that a franchisor could maximize its profits by charging a $\$ 20,000$ annual fixed franchise fee and permitting all consumables to be sold at the market price, which we presume to be competitive. ${ }^{36}$ In that case 50 franchisees would sign up. The franchisor could also charge a $\$ 10,000$ annual franchise fee but sell one or more consumables at a higher-than-market price. The lower fee would induce 50 additional franchisees, or a total of 100, to sign up. Among these franchisees, some of the 50 original ones ("high volume" franchisees) end up paying more because their annual use of the consumables exceeds $\$ 10,000$. Others of the 50 original franchisees ("medium volume") pay less, however, because the increment in consumable prices is less than $\$ 10,000$ and they are thus better off as a result of the tying product price reduction. The 50 "new" franchisees ("low volume") would not have been in the market at all under the single monopoly price. Their gains are a pure consumer welfare improvement. In sum, two groups of franchisees (low volume and medium volume) gain, while a third group (high volume) is worse off. The franchisor profits from the high and low volume franchisees, but loses on the medium volume franchisees. Under most realistic assumptions both economic welfare and consumer welfare are increased.

${ }^{30}$ Ibid.

${ }^{31}$ Ibid.; and see Erik Hovenkamp \& Herbert Hovenkamp Article, 52 Ariz. L.Rev. at 928-945.

32 The cases are collected and discussed in 9 Antitrust Law I1711b1. See also Erik Hovenkamp \& Herbert Hovenkamp Article, 52 Ariz. L.Rev. at 939-944 \& notes.

${ }^{33}$ Erik Hovenkamp \& Herbert Hovenkamp, Id.

${ }^{34}$ Ibid.

${ }^{35}$ E.g., Kypta v. McDonald's Corp., 671 F.2d 1282, 1285 (11th Cir. 1982) (injury must be shown by reference to overcharge in sum of tying and tied product, not by overcharge in tied product alone).

${ }^{36}$ This assumption avoids concerns about double marginalization, which do not generally apply if one of the two goods is sold under competition. See 9 Antitrust Law II1712. 
Such arrangements exist across the full range of market structures, from absolutely monopolized to highly competitive. ${ }^{37}$ Both dominant and nondominant firms use ties. As a result monopolizing cannot be the only explanation of such tying and is not very likely an important explanation at all. When a practice increases output the inference of consumer benefit must be regarded as very strong.

To be sure, one cannot rule out the possibility that some ties reduce output, most likely because they are accompanied by price increases in the tying product, or at least by prices that are not changed. The literature on bundled discounts does hypothesize situations in which bundling is accompanied by a price increase in the primary product. But in those cases the cause of the harm is foreclosure, or exclusion, rather than monopoly. ${ }^{38}$ In any event, contractual ties do not have an analogue.

One argument against some types of price discrimination is that it can reallocate output from higher value to lower value consumers, and this would constitute a form of injury. This type of redistribution occurs when a seller segregates two or more groups of customers a priori and sells to them at different prices. For example, suppose that the seller segregates commercial and residential users, charging the first $\$ 100$ and the second $\$ 60$ per unit. ${ }^{39}$ A commercial buyer willing to pay $\$ 99$ will be turned away, while a residential purchaser willing to pay $\$ 61$ will be served. This characteristic of "third degree" price discrimination entails that such discrimination schemes cannot increase welfare unless they also increase output. ${ }^{40}$ Tying arrangements, however, are an instance of "second degree" price discrimination in which a common set of prices and terms are announced in advance and customers select how much they want to purchase. ${ }^{41}$ Such arrangement do cause a deviation from perfect competition to the extent that all buyers pay less than the standalone price for one product and more for a different one; but there is no transfer from higher value to lower value purchasers. For example, if a printer manufacturer ties by dropping the price of a printer by $\$ 100$ and increasing the price of cartridges by $\$ 10$ to a price of $\$ 25$, then each customer will purchase cartridges until the value she places on the next cartridge falls to $\$ 25$. At the margin each customer will obtain the same value.

Third, the probability of double marginalization must be taken into account anytime a tie joins two markets in which prices are above costs. Some tying cases have involved tied commodities, such as ink or salt, that were sold in highly competitive markets. In these cases tying is not likely to produce significant savings from the avoidance of market power in the secondary market. But many other cases, often in higher technology markets, cannot be so characterized. Further, the price discrimination explanation for tying does not depend on the existence of double marginalization.

${ }^{37}$ See, e.g., Siegel v. Chicken Delight, Inc., 448 F.2d $43\left(9^{\text {th }}\right.$ Cir. 1971) (competitively structured fast food market in which defendant franchisor was a minor player). On the necessity of market power in the tying product, see 10 Antitrust Law, Ch. 17C.

${ }^{38}$ See, e.g., Patrick Greenlee, David Reitman \& David S. Sibley, An Antitrust Analysis of Bundled Loyalty Discounts, 26 Int'l J. Indus. Org. 1132, 1137 (2008); Barry Nalebuff, Exclusionary Bundling, 50 Antitrust Bull. 321, 324-327 (2005); and see Antitrust Law I7749d7 (supp.).

${ }^{39}$ Gen. Talking Pictures Corp. v. Western Elec. Co., 305 U.S. 124 (1938) (licensing of technology to produce sound amplifiers at different rates to producers for commercial use and for home use); ProCD, Inc. v. Zeidenberg, 86 F.3d 1447 (7th Cir. 1996) (licensing of database to commercial and residential users at different rates). See Christina Bohannan, Copyright Preemption of Contracts, 67 Maryland L. Rev. 616 (2008).

${ }^{40}$ See Erik Hovenkamp \& Herbert Hovenkamp Article, 52 Ariz.L.Rev. at 934.

${ }^{41}$ Other common examples are quantity discounts or price gradations by customer-chosen classes of service. See id. 
In the tying context, double marginalization occurs when two firms make complementary goods (such as a printer and ink cartridge, or a stereo and speaker set) and each of them has some power over price. The markets need not be monopolized, but they must exhibit prices above the competitive level such as characterize an oligopoly. In that case each firm selling only one of the two goods will set a price that is "too high" in relation to the price being set by the complementary good. If the two firms were able to bargain with each other they would each increase output and offer a lower joint price, but only if each could be assured of selling the companion to the sale that the other made at the lower price. ${ }^{42}$

To take a simplified illustration, I758 showed the impact of double marginalization in vertical distribution when the upstream firm ("manufacturer") is a monopolist. As a variation, suppose that a manufacturer of stereos sells them at $\$ 300$ each to a dealer who adds speakers and sells them to customers. The competitive markup for adding speakers and retailing the units is $\$ 100$, but in this case the dealer charges $\$ 200$. At that price the stereo manufacturer is losing money because its output is too low. The example illustrates the high degree of artificiality in our distinction between vertical and complementary relationships: if the stereo manufacturer sells to the dealer, who adds speakers and resells to customers, we describe this relationship as "vertical." By contrast, if the first firm makes stereos and the second firm makes speakers and each sells to customers who use them in pairs, then the relationship is regarded as complementary. The economic analysis does not differ significantly, however. In this case, the stereo manufacturer maximizes its output and profits when the speaker markup is competitive. Faced with excessive markups in speakers, the stereo maker would have an incentive to make and add its own speakers, increasing output to the single-monopoly level and reducing prices. Alternatively, the stereo maker and speaker maker might agree on the single monopoly price and output, which would be a lower price for consumers and a higher output for each of them.

However, in both the case where the stereo maker entered the speaker market and the case in which it reached an agreement with an independent speaker maker, the profitability of the arrangement would depend on the sales of stereo-plus-speaker as a package. Just as in the purely vertical arrangement, joint maximization and the lower prices that result occur only when a single firm sells in both markets itself or the two firms coordinate their output and sell together. A bundled discount typically achieves this result; by selling the bundle in a single transaction the seller eliminates double marginalization and thus maximizes its profits at a lower price. ${ }^{43}$

Finally, the importance of cost savings or improved product or services cannot be underestimated. Indeed, this is an important reason that tying is so ubiquitous in competitive as well as noncompetitive markets. The fact is that most of the litigated ties over the past century have not involved monopolists, and many have involved firms in quite competitive markets. The lengthy Paragraphs on defenses in this book offer a survey of the cases, with the explanations of joint cost savings and quality control tending to dominate. $^{44}$

In sum, tying is not even arguably in the range of "naked" practices whose profitability depends on market power. ${ }^{45}$ Even in the case of a tying monopolist, the tie most typically serves to increase output via price discrimination. Otherwise it is used to control the double marginalization that occurs when firms in the secondary market have power as well. And the defenses of production or distribution cost savings or product improvement apply just as much to monopolist as to competitors. When the tying firm is not a monopolist, as has been true in most cases, the rationales for presuming harm are even weaker.

\footnotetext{
${ }^{42}$ See 9 Antitrust Law I1712.

${ }^{43}$ See 3A \& 3B Antitrust Law IIIT749, 758.

${ }^{44}$ See 9 Antitrust Law IIT1716-1717 (on the rationales); and TITI1761-1762 (raised as defenses).

${ }^{45}$ See 11 Aantitrust Law T1906.
} 